UDC 332; DOI 10.18551/rjoas.2022-01.15

\title{
SEED MAIZE SOURCES AND EFFECTS ON YIELD AND FARM INCOME IN TECHIMAN MUNICIPALITY, GHANA
}

\author{
Nimoh Fred, Tham-Agyekum Enoch Kwame*, Agyemang Mike Adu, Cudjoe Emmanuel, \\ Alli Titilayo, Annor Kwadwo \\ Department of Agricultural Economics, Agribusiness and Extension, Faculty of Agriculture, \\ Kwame Nkrumah University of Science and Technology, Ghana \\ *E-mail: ektagyekum@knust.edu.gh
}

\begin{abstract}
Using a cross-sectional survey data on 232 respondents, this study investigates the sources of seed maize and their effects on yield and farm income in the Techiman Municipality of Ghana. The logit model and multiple linear regression were used to analyze the factors influencing choice of seed source and effect on yield, respectively. The t-test was used to compare the mean yields and farm income from the various sources of seed maize. The study found that majority of the farmers obtain their seed maize from the informal seed system. Extension services, maturity, pest and diseases resistant, credit access and cost of seed maize were found to influence farmers' choice of seed source. Farm size, volume of herbicide applied, cost of labour and volume of fertilizer applied were found to influence yield. Although the formal seed system recorded a higher mean yield but a lower mean profit relative to the informal seed system, there was no statistically significant difference. The study recommends that, policies that minimize the incidence of cost should be implemented by the Government to increase adoption of the formal seed system for higher yield.
\end{abstract}

\section{KEY WORDS}

Extension services, income, seed cost, seed longevity, seed maize sources, yield.

Ghana's agriculture remains predominantly small scale and the majority of farmers are food crop farmers producing mainly for home consumption (MoFA, 2012). Maize is a principal crop and major food in most African and south American countries. Maize is one of the most important crops produced and consumed in Ghana, accounting for more than 50\% of local cereal production. Maize (Zea mays) is a versatile, growing across range of ecological zones (de Groote et al., 2013; Asenso, 2001).

Maize production provides socioeconomic benefits such as food security, income generation and easing off poverty. Maize is also an important element in poultry and livestock sector and as alternative in brewing sector and also a major source of carbohydrate. Maize yield averaged $4.9 \mathrm{t} \mathrm{ha}^{-1}$ globally in 2009 (Edgerton, 2009). However, yields in major maize growing areas in the developing world still lag behind the world average, producing only about $3.1 \mathrm{t}^{\text {ha-1 }}$ (Pixley et al., 2009). Maize has been cultivated in Ghana for several hundred years. After being introduced in the late $16^{\text {th }}$ century, it soon established itself as an important food crop in the southern part of the country (Morris, Tripp, \& Dankyi, 1999).

The economic importance of maize and its role in ensuring food security in Ghana cannot be over emphasized (Akramov et al., 2012). Annual production has been more than $1,000,000$ MT since 2000, averaging 1,772,300MT over the period 2009 to 2012. It accounts for about 20\% of Ghana's Gross Domestic Product in 2014 and employs more than half of the workforce, and has the potential to promote overall growth of the economy and have a positive impact on food security (MoFA, 2000; Akramov et al., 2012).

Seed is a major investment by smallholder farmers, but across Africa there are multiple supply chain pathways, within which it is important to understand the different actors (breeders, seed companies, agro-input traders, etc.) and the behaviour of farmers that underpins more sustainable models of seed production, distribution and related impacts in farmers' fields (Akramov et al., 2012). Seed is the most precious resource of farmers and 
concern about variability of agricultural systems usually centre on the diversity and stability of seed supply system. Seed is a vehicle linked to promoting productivity, nutrition and resilience. Seed can be the conduit for moving new varieties, giving farmers access to more productive, yield-enhancing traits (Morris et al., 1999).

Seed represents a key technology component for the improvement of agricultural productivity and in many countries of sub-Saharan Africa (SSA). Improving the quality of seed of any preferred variety is the basis for agricultural productivity improvements (Tripp, 1998). Increased yield and productivity as well as farmer's income are directly related to the availability and adoption of improved crop varieties (Asenso, 2001; Buah et al., 2011). Researchers have produced high yielding and secured varieties in an attempt to bridge the gap. Among these varieties are the Quality Protein Maize (QPM) which is a hybrid maize produced in 1997, Mamaba which is a $25-30 \%$ higher yielding variety than others of the same life-cycle; Mamaba yields 5-7 t/ha and is also disease resistant with early maturity; Obaatanpa released in 1992 has a potential yield of 4.6 t/ha (MoFA, 2012; Akramov et al., 2012).

However, current seed supply is estimated as insufficient (shortfall of approximately $8,000 \mathrm{t}$ ) and in 1982, 500 acres of maize were cultivated and in 2006 seed supply was sufficient for 444 acres (22\%) of the cropped area (Oyewo, 2011). Lyon and AfikorahDanquah (1998), noticed that only $13 \%$ of maize farmers in Ghana obtained fresh seed of variety they are already growing. Yield data from the FAO suggest that yield increase in Ghana was of about $1.1 \%$ per year and is ranking among the lowest in the world, even if compared with countries of similar conditions. The average maize yield in Ghana remains one of the lowest in the world, much lower than the average for Africa south of the Sahara. In 2012, maize yields in Ghana averaged 1.2-1.8 metric tons ( $\mathrm{mt}$ ) per hectare, far below the potential yield of 4- 6 metric tons (mt) per hectare (ha) achieved (Oyewo, 2011). The gap between production and consumption of maize in recent years in Ghana present the country with growing import bills and higher prices for consumers.

Anecdotal evidence shows that in the past few years, farmers in Techiman have had lower yield per acre based on their seed maize for planting. Maize harvested were not of good quality which did not meet the market preference by most consumers. In addition, various studies have been conducted in this area of seed sources. For instance, Ayamga (2018) conducted a study on access to hybrid seeds in Ghana with a specific focus on smallholder farmers in Tamale. Amanor (2010) studied about participation, commercialisation and actor networks in the political economy of cereal seed production. Again, Amanor (2011) studied about farmer participation in pro-poor seed markets. McGuire (2008) looked at securing access to seed in respect of the social relations and sorghum seed exchange in Eastern Ethiopia. McGuire and Sperling (2011) studied the links between food Security and seed security. Rahaman (2018) studied about farmers' practices in soybean (glycine max) storage and their effects on viability and vigour of seeds. Khan et al., (2015) looked at the influence of seed source on growth and yield of wheat. Mutai (2018) studied the effect of seed source and post-harvest handling techniques on seed quality and yield of soybean. Currently, there is limited study on the effect of seed maize sources on farmers' yield and income. Therefore, this study sought to identify the sources of seed maize and its effects on yield and income of maize farmers: What are the major seed maize sources used by farmers? What are the factors influencing the sources of seed maize? What are the effects of source of seed maize on farmers' yields? What are the profit levels in relation to formal and informal sources of seed maize? What are the constraints associated with sources of seed maize?

\section{METHODS OF RESEARCH}

Survey design was adopted for the study. A cross-sectional survey method was used to collect data on current attitudes, opinions on the use of improved maize seeds. The total population of Techiman municipality is purported to have about 60,000 maize farmers. Techiman municipality is noted with the largest market for maize in the sub region. Multistage 
sampling method was used. Firstly, purposive random sampling was used to select communities because of the large number of maize farmers and nearest to each. The communities include Aworoopataa (154), Anitiefi (17), Akisimasu (13) and Tanoso (48).

Secondly, simple random sampling was used to obtain the sample size for the study. Sample size for the study was 232 respondents.

Questionnaire was used as the main instrument for collecting data for our study and was administered in local dialect and English to obtain quality data. A structured questionnaire was used. The questionnaire consisted of two sections. Data was analyzed by descriptive and inferential statistics. Descriptive research design will focus on obtaining both qualitative and quantitative data for the study.

The Logistic Regression was used to determine the factors influencing the source of seed maize.

$$
\mathbb{y}=\log \left[\frac{P_{i}}{\left(1-P_{i}\right)}\right]=\beta_{0}+\sum_{i j-i}^{n k} \beta X_{i j}+\varepsilon_{i}
$$

Where: $P_{i}=$ Probability that a farmer uses formal system; $\beta_{0}=$ Constant; $\sum \beta X_{i j}=$ Vector of all the explanatory variables; $\varepsilon_{i}=$ error term.

The empirical model for the study was specified as:

$$
Y=B_{0}+B_{i} X_{i}+\varepsilon
$$

Where: $Y$ = Sources of Seed Maize (Formal Seed System / Informal Seed System).

Table 1 - Measurement of Variables for Logit Regression

\begin{tabular}{|l|l|l|}
\hline Independent Variables & Measurement & A Prior Sign \\
\hline Age(X1) & Years & $+/-$ \\
\hline Gender (X2) & $\begin{array}{l}\text { Male } 1 \\
\text { Female }=0\end{array}$ & + \\
\hline Educational Level(X3) & Years & $+/-$ \\
\hline Farm Size (X4) & Acres & $+/-$ \\
\hline Pest and Disease Resistance (X6) & $\begin{array}{l}\text { Resistant }=1 \\
\text { Non Resistant }=0\end{array}$ & + \\
\hline Income of Farmers(X8) & GHS & $+/-$ \\
\hline Farmers perception about maturity of seeds (X9) & $\begin{array}{l}\text { Early Maturity }=1 \\
\text { Late Maturity }=0\end{array}$ & $+/-$ \\
\hline Fertilizer Requirement(X10) & $\begin{array}{l}\text { More }=1 \\
\text { Less }=0\end{array}$ & $+/-$ \\
\hline Access to Extension Services (X11) & $\begin{array}{l}\text { Yes }=1 \\
\text { No }=0\end{array}$ & + \\
\hline Cost of seeds & $\begin{array}{l}\text { High }=1 \\
\text { Low }=1\end{array}$ & + \\
\hline Farmers Perception about longevity of seeds (X13) & $\begin{array}{l}\text { Longer Storage Duration }=1 \\
\text { Shorter Storage Duration }=0\end{array}$ & + \\
\hline
\end{tabular}

The Multiple Linear Regression was used to assess the effect of the source of seed maize on yield:

$$
\gamma=\alpha+\beta_{i} x_{i}+\varepsilon_{o}
$$

Where: $x=$ independent variables; $\beta_{i}=$ the coefficient of $x ; \gamma=$ Yield (Bags per acre); $\varepsilon_{o}=$ Error Term.

$$
\gamma=\alpha+\beta_{1} x_{1}+\beta_{2} x_{2}+\beta_{3} x_{3}+\beta_{4} x_{4}+\beta_{5} x_{5}+\beta_{6} x_{6}+\beta_{7} x_{7}+\beta_{8} x_{8}+\beta_{9} x_{9}+\varepsilon_{\varepsilon_{0}}
$$

The Paired Sample T-Test was used to compare the means of yield from the various sources of seed maize to see if they have significant difference. The T-test statistic was also used to determine the margin of each source of seeds on farmers' income. 
Table 2 - Measurement of Variables for Linear Regression

\begin{tabular}{|c|c|c|}
\hline INDEPENDENT VARIABLES & MEASUREMENT & A PRIOR SIGN \\
\hline \multicolumn{3}{|l|}{ Socio-economic factors } \\
\hline Gender (X2) & Male $=1 /$ Female $=0$ & + \\
\hline Experience Level (X3) & Years & $+/-$ \\
\hline Farm Size (X4) & Acres & $+/-$ \\
\hline Household size (X5) & Number of persons & $+/-$ \\
\hline Source of Income (X6) & Non-farm $=1 /$ Otherwise $=0$ & + \\
\hline \multicolumn{3}{|l|}{ Bio-Physical factors } \\
\hline Weed Incidence and Pest Infestation (X7) & High $=1 /$ Otherwise $=0$ & + \\
\hline Sources of seeds $(X 9)$ & $\begin{array}{l}\text { Formal Seed System }=1 \\
\text { Informal Seed System }=0\end{array}$ & $+/-$ \\
\hline Variety of seeds & Improved $=1 /$ Local $=1$ & + \\
\hline Application of herbicides & Liter per hectare & $+/-$ \\
\hline
\end{tabular}

The net profit analysis was employed to estimate the profit levels on sources of seed maize between the formal and informal seed system. Thus, Profit = Revenue - Cost; Net Profit $=$ Gross Profit - All Expenses.

The Kendall Coefficient of Concordance (W) was used to know farmer's constraints associated with each source:

$$
\text { Kendall's } \mathbf{W}=\frac{12 S}{m^{2}\left(n^{3}-n\right)}
$$

Where:

- If $W=1$, then judges or survey have the same order;

- If $W=0$, then there is no overall trend of agreement;

- $\mathrm{S}=$ sum of squared deviations;

- $m=$ number of judges of respondents ranking the objects;

- $\mathrm{n}=$ number of objects or attributes that is evaluated by respondent.

\section{RESULTS AND DISCUSSION}

This section presents and discusses the results of the socioeconomic characteristics of the respondents. The socioeconomic characteristics include age, household size, experience level, marital status and educational level.

Table 3 - Socio-Economic Characteristics of Maize Farmers

\begin{tabular}{|c|c|c|c|c|}
\hline Variables & Minimum & Mean & Maximum & Percent \\
\hline Age & 21 & 47 & 79 & \\
\hline Household size & 3 & 9 & 29 & \\
\hline Experience level & 1 & 25.43 & 20.37 & \\
\hline \multicolumn{5}{|l|}{ Marital status } \\
\hline $\begin{array}{l}\text { Married } \\
\text { Single } \\
\text { Divorced } \\
\text { Widowed } \\
\text { Separated }\end{array}$ & & & & $\begin{array}{l}89.1 \\
4.1 \\
3.4 \\
2.7 \\
0.7 \\
\end{array}$ \\
\hline \multicolumn{5}{|l|}{ Educational level } \\
\hline $\begin{array}{l}\text { Junior high } \\
\text { Primary } \\
\text { Senior } \\
\text { Tertiary } \\
\text { No education }\end{array}$ & & & & $\begin{array}{l}39.5 \\
15.6 \\
6.8 \\
0.7 \\
37.4\end{array}$ \\
\hline
\end{tabular}

Source: Field Data, 2021.

From the Table, the average age of the sampled respondents was 47 years with a minimum age of 21 years and a maximum age of 79 years. This suggests that most of the respondents were quite old. This concurs with the findings of Alene et al., (2009) who 
suggested that older farmers would most likely not be willing to spend more time to obtain information on improved technologies compared to younger farmers. The average household size of the respondents was 9 members with a minimum of 3 persons and a maximum of 29 persons. The mean years of farming experience is 25.43 which implies that on the average, farmers in Techiman municipality have acquired 25years of farming experience. The minimum years of farming experience level is 1 year and the maximum is 70 years. The distribution of marital status of the respondents show that majority $(89.1 \%)$ of the maize farmers were married. The educational levels of the respondents show that the majority $(39.5 \%)$ of the maize farmers had attained junior high education. This was followed by $15.6 \%$ who had primary education. About $6.8 \%$ had obtained senior high education and $0.7 \%$ had attained tertiary education. Most of the farmers had no formal education (37.4\%).

Table 4 - Socio-Economic Characteristics of Formal and Informal Seed Sources

\begin{tabular}{|c|c|c|c|c|c|c|c|c|}
\hline \multirow{2}{*}{ Variables } & \multicolumn{3}{|c|}{ Informal Seed Source } & \multicolumn{3}{c|}{ Formal Seed Source } \\
\cline { 2 - 9 } & Mean & Min & Max & SD & Mean & Min & Max & SD \\
\hline Age & 46 & 21 & 75 & 14.83 & 48 & 23 & 79 & 14.83 \\
\hline Years of Formal Education & 5 & 0 & 24 & 5.13 & 6 & 0 & 17 & 5.45 \\
\hline Years of Farming Experience & 25 & 1 & 70 & 14.00 & 26 & 3 & 60 & 14.37 \\
\hline Household Size & 8 & 3 & 27 & 4.64 & 10 & 3 & 29 & 5.66 \\
\hline Years of Maize Farming & 21 & 1 & 70 & 13.77 & 20 & 1 & 55 & 13.00 \\
\hline Farm Size & 5 & 0.5 & 32 & 4.78 & 5 & 0.5 & 32 & 5.59 \\
\hline Distance in Kilometers & 0.15 & 0 & 6 & 0.77 & 4.4 & 0 & 32 & 8.84 \\
\hline Volume of herbicide applied (liters) & 5.7 & 0 & 48 & 8.43 & 6.3 & 0 & 32 & 6.96 \\
\hline Bags of fertilizer applied (kg) & 4.2 & 0 & 45 & 8.40 & 5.25 & 0 & 50 & 10.07 \\
\hline Quantity of Seed Maize Planted (kg) & 4.3 & 0 & 70 & 4.39 & 9.5 & 0 & 72 & 12.68 \\
\hline Cost of Seed Maize & 17.29 & 0 & 300 & 50.84 & 140.6 & 0 & 1184 & 206.86 \\
\hline Quantity Harvested (kg) & 21 & 1 & 200 & 29.00 & 27 & 3 & 200 & 39.59 \\
\hline Quantity Sold & 19 & 0 & 198 & 28.92 & 22 & 2 & 117 & 28.31 \\
\hline Price of Seed Maize sold (per kg) & 2.3 & 0 & 60 & 7.36 & 31.7 & 0 & 263 & 60.05 \\
\hline Cost of labour & 100.94 & 0 & 800 & 140.61 & 128.49 & 0 & 600 & 128.22 \\
\hline
\end{tabular}

Source: Field Data, 2021.

Table 4 shows the various characteristics of farmers who used informal seed sources and informal seed sources of respondents. The average age of farmers who used informal seed source and farmers who used the formal seed source were 48 and 46 respectively. The experience level of farmers who used informal seed averaged 25 and formal source averaged 26. The household size of farmers who used informal seed averaged 8 and formal source averaged 10. The years of maize farming of farmers who used informal seed averaged 21 and formal source averaged 20. The farm size of farmers who used informal seed averaged 5 and formal source averaged 5 . Farmers who use informal seed sources travel a distance of $0.15 \mathrm{~km}$ to their farms while those who use formal seed sources travel a distance of $4.4 \mathrm{~km}$ to their farms. The volume of herbicide applied by maize farmers who use informal seed sources was 5.7L while those who use informal seed sources was $6.3 \mathrm{~L}$. The bags of fertilizer applied by maize farmers who use informal seed sources was $4.2 \mathrm{~kg}$ while those who use formal seed sources was $5.25 \mathrm{~kg}$. The quantity of seed maize planted by maize farmers who use informal seed sources was $4.3 \mathrm{~kg}$ while those who use formal seed sources was $9.5 \mathrm{~kg}$. The cost of informal seed maize was $17.29 \mathrm{GHc}$ while the formal seed maize was $140.06 \mathrm{GH}$ c. The quantity of maize sold by farmers who use informal seed sources was 19bags while those who use formal seed sources was $27 \mathrm{bags}$. The price of seed maize sold (per $\mathrm{kg}$ ) for those who use informal seed sources was 2.3GHc while those who use formal seed sources was $31.7 \mathrm{GH}$. The cost of labour for maize farmers who use informal seed sources was $100.94 \mathrm{GH} \phi$ while those who use formal seed sources was 128.49GHc.

From the results, it can be deduced that maize farmers who use informal seed sources were older in age, less farming experience, more maize farming experience, travel less distance to their farms, apply less volume of herbicide, fertilizers and planting seeds than the maize farmers who use formal seed sources. Formal seed sources are more expensive, 
produce more bags of maize, sell more bags of maize and has higher cost of labour than the informal seed sources. The farm size of farmers who used both the informal and formal seed was the same.

Table 5 - Major Sources of Seed Maize used by farmers

\begin{tabular}{|l|l|l|l|}
\hline Category & Sources & Frequency & Percentage \\
\hline \multirow{4}{*}{ Informal } & Local Market & 17 & 7.33 \\
\cline { 2 - 4 } & Owned Seeds & 95 & 40.95 \\
\cline { 2 - 4 } & Neighbors & 12 & 5.17 \\
\hline \multirow{3}{*}{ Formal } & MoFA & 46 & 19.83 \\
\cline { 2 - 4 } & Agro dealers & 38 & 16.38 \\
\cline { 2 - 4 } & NGOs & 24 & 10.34 \\
\hline Total & 232 & 100.0 \\
\hline
\end{tabular}

Source: Field Data, 2021.

Respondents were asked about their major sources of seed maize. About $41 \%$ of the respondents indicated that their major source of seed maize was "owned seeds" [informal]. This was followed by MoFA (20\%), agro dealers (16\%), NGOs (10\%) [formal], local market $(7 \%)$ and neighbours (5\%) [informal]. This suggests that majority of farmers in Techiman depend mainly on their own seeds (informal). Futas (2016) noted that farmers use saved seed to reduce costs and their high degree of familiarity with the variety and quality of production. This clearly states why $41 \%$ of the maize farmers used owned seed in Techiman municipality.

A summary of the sources of the seed maize shows that maize farmers gain majority of their seeds from informal sources (53\%) while about $47 \%$ make use of formal sources. The result is confirmed by another study that asserted that about $40 \%$ of maize farmers in that study used recycled maize seed from their harvest while about $30 \%$ of the respondents purchased maize seed from input suppliers or agro- dealers. Other sources of seed from which farmers bought maize seed were fellow farmers, research centres and local markets (Nchembi, 2017). Crissman et al., (1993) also found out that the informal seed sector supplies about $80 \%$ of the seed needs of farmers and is the main source of seed for staple crops. The result is consistent with their findings which show that most farmers in Techiman municipality use informal seed source for production. The informal seed supply systems should not be confused with "black market" situations that exist in several countries of the region and affect both the formal and the informal systems. The informal seed supply system consists of farmer-managed seed production activities and is based on indigenous knowledge and local diffusion mechanisms. It includes methods such as retaining seed onfarm from previous harvests to plant the following season, and farmer-to-farmer seed exchange networks. There has been little or no emphasis on the informal seed supply sector and little is known about its operation in the region. As a result, documentation with regard to the informal seed sector is scarce (https://www.fao.org/3/y2722e/y2722e0d.htm)

Table 6 - Logit regression

\begin{tabular}{|c|c|c|c|c|}
\hline Formal/Informal Seed System & Coefficient & Marginal Effects dy/dx & $z$ & $\mathrm{P}>\mathrm{Z}$ \\
\hline Years of formal Education & $0.03(0.05)$ & 0.01 & 0.58 & 0.56 \\
\hline Extension Services & $1.31(0.55)$ & 0.33 & 2.38 & $0.02^{* *}$ \\
\hline Maturity & $1.46(0.71)$ & 0.37 & 2.07 & $0.04^{\star \star}$ \\
\hline Gender & $1.17(0.52)$ & 0.29 & 2.23 & 0.13 \\
\hline Pest and Diseases Resistant & $2.05(0.99)$ & 0.51 & 2.06 & $0.04^{* *}$ \\
\hline Fertilizer & $-0.38(0.50)$ & -0.09 & -0.76 & 0.45 \\
\hline Agricultural Production & $-0.96(1.15)$ & -0.24 & -0.83 & 0.41 \\
\hline Seed Maize Vigor & $-1.01(0.84)$ & -0.25 & -1.19 & 0.23 \\
\hline Access to credit & $1.32(0.540)$ & 0.31 & 2.44 & $0.00^{\star \star \star}$ \\
\hline Longevity of seeds & $-1.46(0.51)$ & -0.36 & -2.84 & 0.50 \\
\hline Seed cost & $0.02(0.00)$ & 0.00 & 3.72 & $0.00^{* \star *}$ \\
\hline cons & $-2.46(1.47)$ & - & 1.47 & 0.09 \\
\hline
\end{tabular}

Source: Field Data, 2021.

$R^{2}=0.64 ;$ Adj. $R^{2}=0.63 ;{ }^{* *} P<5 \% ;{ }^{* * *} P<1 \%$. 
In explaining what happens in the formal seed sector, Hintze et al., (2002) and Bernard et al., (2010) indicated that farmers who tend to continue using certified seed (formal sources) are those who have ability to buy them and incur cost in searching for them from different sources depending on the type of the variety. On the other hand, if farmers are constrained with resources they tend to obtain seed through recycling (Doss, 2006). This can be done when seed are carried over from the previous harvest either by the farmers themselves through the traditional on-farm selection process whereby the farmer identifies next year's seed stock while it is still maturing in the field and gives it special protection or by buying from preferred seed stock kept by other farmers in the same locality (FAO/WFP, 2009).

The logit model was used to determine the factors that determine the type of seed system choices made by the maize farmers. From the model, extension services, maturity, pest and diseases resistant were significant at $5 \%$ while access to credit and seed cost were significant at $1 \%$. The $\mathrm{R}^{2}$ of $38 \%$ shows that the factors stated above explains about $38 \%$ of the variations displayed in the dependent factor. Hence, maize farmers make their choices of seed maize sources based on the following factors; extension services, maturity, gender, longevity of seeds, pest and disease resistance and seed cost. All the factors except longevity of seeds were positive.

An interpretation of the factors shows that a unit increase in extension services will result in a 33\% increase in the likelihood that farmers will go for formal seed system. Kaliba et al., 2000; Tembo and Haggblade (2003) and Mavunganidze et al., (2013) argued that extension services to the household is positive and significantly increases the likelihood of choosing agricultural technologies. Contrary to the findings of this study, Kassie et al., (2012) found that farmer's access to extension services is expected to decrease the probability of choosing a variety by $18 \%$. This shows that as farmers have access to extension services they are less likely to choose the variety perhaps due to much emphasize given to other crops in the areas.

A unit increase in maturity period will result in a 37\% likelihood that farmers will go for the formal seed system. Formal seeds mature early compared to seeds from the informal system. Farmers therefore prefer seeds from the formal system. This suggests that a short maturing seed will be preferred by maize farmers. This is consistent with Kaliba et al., (2000) who argued that maize farmers prefer short maturing varieties because they usually yield less than long maturing varieties but can escape moisture stress easier than long maturing varieties. This could probably be reason why more farmers reported to have grown local variety compared to the foreign ones. Early maturity is a critical attribute for farmers because it may be linked to the ability to avoid drought. The shorter the period of growing the smaller the risk the crop been affected by drought (Hintze et al., 2002).

The empirical results also show that the pest and disease resistance was significant at $5 \%$ level. This implies that a unit increase in seed resistant, will increase the probability of using formal maize seed source by about $28 \%$, all things being equal. This means that the higher the pest and disease resistance of seeds, the more likely they would go for formal seed source. Access to credit was significant at 5\%. A unit increase in credit access will result in $31 \%$ likelihood that farmers will go for formal seed source. Farmers with credit access will have the purchasing power to buy from the formal seed source (inputs). The positive effect of credit access is in line with findings by Ouma et al., (2002) who noted that credit enables farmers to buy inputs required by improved technology.

A unit increase in seed cost will result to a $4 \%$ likelihood that farmers will go the formal seed system. Seeds from the formal system are of high quality compared to that from the formal seed system. Due to this, farmers go for the formal system even though prices are higher than that of informal seed system. Contrary to the findings observed in other studies, Nchembi (2017) and Ransom et al., (2003) found that farmers are likely to use maize variety as long as this variety shows an outstanding yield as compared to others.

A multiple linear regression model was employed to access the effect of sources of seed maize on yield. The results of multiple linear regression model are presented in Table 7. Among the factors included in the model were, years of formal education, farm size, 
quantity of seed planted, major source (formal and informal), herbicides application, labour, quantity of fertilizer, pest and disease resistant and income of farmers (agricultural production), improved variety of seeds. The empirical results show that, farm size allocated to maize, use of improved seeds, volume of herbicide applied, labour and fertilizer are significant variables that affect yield in maize production.

Table 7 - Summary of results from linear regression

\begin{tabular}{|c|c|c|c|c|}
\hline Variables & Coefficient & Standard Error & $\mathrm{T}$ & $\mathrm{P}>\mathrm{t}$ \\
\hline Years of Formal Education & 0.41 & 0.412 & 0.98 & 0.33 \\
\hline Years of farming & 0.07 & 0.16 & 0.41 & 0.69 \\
\hline Farm Size Allocated to Maize & $0.72^{* * *}$ & 0.26 & 2.81 & 0.01 \\
\hline Quantity of Seed Maize planted & 0.26 & 0.20 & 1.31 & 0.19 \\
\hline Use of Improved Seeds & $7.68^{*}$ & 4.39 & 1.75 & 0.08 \\
\hline Volume of Herbicide Applied & $0.01^{*}$ & 0.00 & 1.82 & 0.07 \\
\hline Labour & $0.09^{* * *}$ & 0.03 & 2.86 & 0.00 \\
\hline Fertilizer & $1.83^{* * *}$ & 0.27 & 6.74 & 0.00 \\
\hline Pest and Diseases Resistant & 5.15 & 8.13 & 0.63 & 0.53 \\
\hline Income of Farmers & 1.55 & 8.58 & 0.18 & 0.86 \\
\hline cons & -7.34 & 10.10 & -0.73 & 0.47 \\
\hline
\end{tabular}

$R^{2}=0.53 ;$ Adj. $R^{2}=0.50 ;{ }^{* *} P<5 \% ;{ }^{* *} P<1 \%$.

Source: Field Data, 2021.

From Table 7, the elasticity of land size was positive. This implies that, a $1 \%$ increase in an acre will increase maize yield by $0.72 \%$. The larger the farm size, the higher the yield. The elasticity of use of improved seeds was positive. Variety of seed (improved seed=1) had a positive effect on yield at $10 \%$ significant level. This means that an increase in the use of improved seeds will increase maize yield by $7.68 \%$. Also Owino (2010) found out that improved seed varieties had yield enhancing effect. Volume of herbicide applied has a positive relationship with yield at $10 \%$ significant level. This means that a $10 \mathrm{~L}$ increase in volume of herbicide applied will result to an increase of $0.8 \%$ in maize yield in production. The output elasticity of labour was positive at $1 \%$. This means that an addition to labour by 1 person will improve yield by $0.09 \%$. The output elasticity for fertilizer was positive, indicating that an increase in fertilizer use by 1 kilogram will increase maize production by 1.83 percent. The positive effect of fertilizer is in agreement with findings by De Groote et al (2013), who noted that the intensity use of fertilizer has a major effect on maize yield.

Table 8 - T-Test to compare the Means of Yield from Sources of Seed Maize

\begin{tabular}{|c|c|c|c|c|}
\hline Variable & Informal & Formal & Mean difference & P value \\
\hline Yield & 21.18 & 26.02 & -4.84 & 0.39 \\
\hline
\end{tabular}

Source: Field Data, 2021.

Based on the results above, it is evident that farmers adopting the formal seed system produce more yield per acre of maize $(\mathrm{M}=26.02)$ than those who adopt the informal seed system $(\mathrm{M}=21.18)$. Ordinarily, this makes the formal seed system a better option in terms of maize yield than the informal. This could be because the entire formal sector is mostly directed and controlled by an organization which actually concerns itself with the breeding of seeds and its distribution. Therefore, only certified seeds are distributed. There is a high likelihood that these seeds will yield better than those originating from farmers' own farms. This is confirmed by Dagnoko et al., (2020) who stated that foundation seeds produced under the formal seed system give high yields and good quality. Thus, policy makers should consider involving seed companies and smallholder farmers together with research institutions in the production of foundation seeds. However, the t-test shows that the difference observed in yield between the formal and informal seed system was not statistically significant. Therefore, there is no evidence to say the mean yield of informal seed source is different from the mean yield of formal seed sources. It is therefore concluded that there is no difference between the means of yield of formal and informal seed sources. 
Table 9 - Income Statement Account for Formal and Informal Seed Source

\begin{tabular}{|c|c|c|c|c|}
\hline \multirow{2}{*}{$\mathrm{n} / \mathrm{n}$} & \multicolumn{2}{|c|}{ Informal Seed Source } & \multicolumn{2}{|c|}{ Formal Seed Source } \\
\hline & $\mathrm{GHC}$ & $\mathrm{GH} \Phi$ & $\mathrm{GH} \Phi$ & $\mathrm{GHC}$ \\
\hline Sales & & 2308.75 & & 2448.00 \\
\hline Variable Costs: & & & & \\
\hline Seed Cost & 17.29 & & 136.22 & \\
\hline $\begin{array}{l}\text { Fertilizer: Ammonium } \\
\text { NPK }\end{array}$ & $\begin{array}{l}168.10 \\
189.14\end{array}$ & & $\begin{array}{l}98.00 \\
384.04\end{array}$ & \\
\hline Urea & 33.41 & & 148.25 & \\
\hline Herbicides & 87.10 & & 87.44 & \\
\hline Ploughing Cost & 67.32 & & 82.30 & \\
\hline Cost of labour & 100.94 & & 126.32 & \\
\hline Harvesting Cost & 55.50 & & 122.56 & \\
\hline Transport Cost & 159.60 & & 250.21 & \\
\hline Less: Total Variable Cost & & $(878.40)$ & & $(1435.34)$ \\
\hline Gross Profit & & 1430.35 & & 1012.66 \\
\hline Less Expense: Rent & & $(120)$ & & (184.83) \\
\hline Net Profit & & 1310.35 & & 827.83 \\
\hline
\end{tabular}

Source: Field Data, 2021.

Table 9 shows the sales for informal and formal seed sources GH\$2308.75 and GH\$2448.00 respectively. The informal seed sources recorded lower sales than the formal seed sources. This implies that there was a higher market for formal seed source. However formal seed sources incurred higher variable costs $(\mathrm{GH} \$ 1435.34)$ than informal seed sources (\$878.40). Due to this, the informal seed sources recorded a higher net profit ( $\mathrm{GH} \$ 1310)$, compared to the formal seed sources ( $\$ 827.83)$.

Table 10 - T-Test to Compare Means of Profit from Sources of seed maize

\begin{tabular}{|c|c|c|c|c|c|c|}
\hline Net Profit & Frequency & Mean GHథ & Min. GHథ & Max. GHథ & Mean difference & P value \\
\hline Formal & 63 & 827.83 & -7164 & 13403.00 & $\$ 482.38$ & 0.39 \\
\hline Informal & 84 & 1310.21 & -708 & 25880.00 & & \\
\hline
\end{tabular}

Source: Field Data, 2021.

Table 10 shows the $t$ test to compare the means of net profit for formal and informal seed sources. Based on the results, it is evident that farmers adopting the informal seed system earn more profit $(\mathrm{GH} \phi$ 1310.21) than farmers adopting the formal seed system (GH\$827.83). Adoption of the informal seed system earns more profit than the formal seed system. This could be attributed to the fact that the formal seed system incurs more variable costs compared to the informal seed system. The T-test was run to show whether there was a significant difference between the mean profit of formal and informal seed sources. The null hypothesis was there is no significant difference between the means of yield of formal and informal seed sources, thus, Ho: diff $=0$. Alternative hypothesis which is $\mathrm{Ha}$ : diff $=0$, implies that there was a significant difference between the means of yield of formal and informal seed sources. Alternative hypothesis gave a $p$ value of 0.39 at a statistically significant level of $p<0.05$, the null hypothesis is accepted. Therefore, there was no evidence to say the mean profit of informal seed source is different from the mean profit of formal seed source. This implies that there was no difference between the means of profit of formal and informal seed sources.

For the formal seed system, the Kendall's co-efficient of concordance (W) for the rankings of constraints faced by respondents was estimated to be 0.15 . Thus, implying a strong agreement among the respondents with regards to the rankings provided based on the fact that they really consider the order of seriousness of the constraints, and this could be justified from the results of the use of the formal seed system. The asymptotic distribution gave a significance level value of 0.00 , which is less than 0.01 .

For the informal seed system, the asymptotic distribution gave a significance level value of 0.00 , which is less than 0.01 . The Kendall's co-efficient of concordance (W) for the 
rankings of constraints faced by respondents was estimated to be 0.52 . Thus, implying a strong agreement among the respondents with regards to the rankings provided based on the fact that they really consider the order of seriousness of the constraints, and this could be justified from the results of the use of the informal seed system. Farmers face many constraints with regards to their choice of seed system.

Table 11 - Constraints associated with the maize seed system

\begin{tabular}{|c|c|c|c|c|c|}
\hline \multicolumn{3}{|l|}{ Formal Seed System } & \multicolumn{3}{|l|}{ Informal Seed System } \\
\hline Constraints & $\begin{array}{l}\text { Mean } \\
\text { Score }\end{array}$ & Rank & Constraints & $\begin{array}{l}\text { Mean } \\
\text { Score }\end{array}$ & Rank \\
\hline High Price of Seeds & 2.76 & $1^{\text {st }}$ & Pest Infestation & 1.59 & $1^{\text {st }}$ \\
\hline High Demand for inputs & 2.95 & $2^{\text {nd }}$ & Mould Infestation & 2.62 & $2^{\text {nd }}$ \\
\hline $\begin{array}{l}\text { Non-availability of } \\
\text { seeds }\end{array}$ & 3.75 & $3^{\text {rd }}$ & Poor Seed Treatment & 4.02 & $3^{\text {rd }}$ \\
\hline Short Storing Duration & 3.89 & $4^{\text {th }}$ & Low Nutrient Content & 4.10 & $4^{\text {th }}$ \\
\hline $\begin{array}{l}\text { Pest and Diseases } \\
\text { Infestation }\end{array}$ & 4.25 & $5^{\text {th }}$ & Late Maturity & 4.45 & $5^{\text {th }}$ \\
\hline \multirow[t]{2}{*}{ Resistant to Drought } & \multirow[t]{2}{*}{4.64} & \multirow[t]{2}{*}{$6^{\text {th }}$} & $\begin{array}{l}\text { Inability to Withstand drought and other } \\
\text { stressful conditions }\end{array}$ & 5.23 & $6^{\text {th }}$ \\
\hline & & & Yield Reduction & 5.98 & $7^{\text {th }}$ \\
\hline \multicolumn{3}{|l|}{$\begin{array}{l}\text { Number of Constraints: } 6 \\
\text { Kendall's W: } 0.14 \\
\text { Chi-Square: } 66.528 \\
\text { df: } 5 \\
\text { Asymp, Sig.: } 0.00\end{array}$} & \multicolumn{3}{|l|}{$\begin{array}{l}\text { Number of Constraints: } 7 \\
\text { Kendall's W: } 0.52 \\
\text { Chi-Square: } 169.055 \\
\text { df: } 6 \\
\text { Asymp, Sig.: } 0.00\end{array}$} \\
\hline
\end{tabular}

Source: Field Data, 2021. NB: $1=$ Most Serious, 2= More Serious, 3= Serious, $4=$ Moderately Serious, $5=$ Slightly Serious, $6=$ Least Serious.

From the study the major constraint faced by farmers adopting the informal seed system are, pest infestation, mould infestation, poor seed treatment, low Nutrient count, late maturity, inability to withstand drought and stressful condition, yield reduction. The constraints faced by famers adopting the formal seed system includes the following; high price of seeds, high demand for inputs, non-availability of seeds, short storing duration, pest and disease infestation, resistant to drought. Dagnoko et al., (2020) and Sibiya et al., (2013) also showed that the challenges faced by farmers when considering varietal traits include yielding ability, period of maturity, drought tolerance, resistance to pest and diseases, grain size, number of cobs, adaptation, good taste and ease of getting seed. Factors impeding high performance of the seed sector are all interrelated and therefore deserve attention if high quality seed production and utilization is to be achieved. Instability of weather conditions, particularly fluctuation in rainfall, is among the chief factors that affect seed production. While some of these constraints directly affect the productivity of the seed sector, other limiting factors are related to policy measures (Crawford et al., 2003).

\section{CONCLUSION}

This study identified the sources of seed maize and their effects on farmers' yield and income in Techiman Municipality. A logit regression model was used to examine the determinants of choice of sources of seed maize. Multiple linear regression model was employed to examine the effect of sources of seed maize on yield of farmers. Profitability analysis was done to estimate the profit level of each sources and Kendall's coefficient of concordance was employed to analyse the constraints that influenced the sources of seed maize in Techiman municipality.

It can be concluded farming in the study area is dominated by the adult population. Majority of the maize farmers secure their seed maize from the informal seed system. Access to extension services, maturity, pest and diseases resistant, access to credit, cost of seeds maize were variables that influenced the source of seeds. Farm size, volume of herbicide applied, use of improved seeds, cost of labour and volume of fertilizer applied were 
found to influence yield. The formal seed system recorded a higher mean yield (26.02) than the informal seed system which obtained a mean yield of 21.18. This indicates that seeds from the formal system yield more than the informal seed system. The mean profit of formal and informal seed system Gh\$827.83 and Gh\$1310.21 respectively. The variable costs of the formal system were higher than that of the informal seed system which resulted in the formal seed system recording a lower mean profit. However, the t- test statistics show that there is no significant difference between the formal and informal seed source in terms of yield and income. The major constraint faced by the formal seed source was high cost of seeds and the major constraint faced by the informal seed source was pest infestation.

Farmers adopting the formal seed system incur higher variable costs than those adopting the informal seed system. Therefore, policies that minimize the incidence of cost should be implemented by the government to increase adoption of the formal seed system. Seed agents or dealers and government should distribute pest and diseases resistant seeds, early maturing seeds to maize farmers in rural farming communities to increase the availability, accessibility and use of formal seeds. Policies that increase the flow of information from the extension to farmers are also proposed e.g. improve the extension officer to farmer ratio in rural communities, increase the number of contacts hours between extension agents and farmers through funding of field days and demonstrations. High price of formal seeds discourage farmers from adopting formal seeds for maize production. However, government and non-governmental organizations can implement policies that can subsidize prices of seeds to increase the adoption of formal seeds. Lastly, this study recommends that government and financial institutions to set a minimum rate for maize farmers to facilitate access to credit which will increase productivity as they buy quality inputs for production. Farmers adopting formal seed system, incur higher variable costs than informal seed system. Therefore, policies that minimize the incidence of cost should be implemented by the government to increase adoption of the formal seed system.

\section{REFERENCES}

1. Akramov, K., Malek, M., \& Catherine R. (2012). Analyzing profitability of maize, rice, and soybean production in Ghana: Results of PAM and DEA analysis. Ghana Strategy Support Program (GSSP) Working, 28.

2. Alene, A. D., A. Menkir, S. O. Ajala, A. S. Badu-Apraku, V. Olanrewaju, M. Manyong, and Ndiaye, A. (2009). The Economic and Poverty Impacts of Maize Research in West and Central Africa, Agricultural Economics, 40: 535-550.

3. Amanor, K. S. (2010). Participation, Commercialisation and Actor Networks: The Political Economy of Cereal Seed Production'. FAC Working Paper 16, Brighton: Future Agricultures Consortium

4. Amanor, K. S. (2011). From Farmer Participation to pro-poor Seed Markets: The Political Economy of Commercial Cereal Seed Networks in Ghana', IDS Bulletin 42(4): 48-58.

5. Asenso, O. (2001). Transforming agricultural production and productivity for sustained rapid growth and development. pp.40 pp. ref.16

6. Ayamga, M. B. (2018). Access to Hybrid Seeds in Ghana: A case of Smallholder Farmers in Tamale, International Institute of Social Studies, The Hague, Netherlands

7. Bernard, M., Hellin, J., Nyikal, R. and John Mburu, J., 2010. Determinants for Use of Certified Maize Seed and the Relative Importance of Transaction Costs Contributed. Paper presented at the Joint 3rd African Association of Agricultural Economists (AAAE) and 48th Agricultural Economists Association of South Africa (AEASA) Conference. AEASA: Cape Town, South Africa, pp. 3-10.

8. Buah, S. S. J., Nutsugah, S. K., Kanton, R., A., L., Atokple, I. D. K., Dogbe, W., Karikari, A. S., \& Ndiaye, K. (2011). Enhancing farmers' access to technology for increased rice productivity in Ghana. African Journal of Agricultural Research, 6(19), 4455-4466.

9. Crawford, E., Kelly, V., Jayne, T. S., and Howard, J. (2003). Input use and market development in Sub-Saharan Africa: An overview. Food Policy 28: 277-292. 
10. Dagnoko, S., F. Camara, F., N. Sangaré, N., Aoga, A., Baltissen, G., Niangaly, O., Traoré, A. B. M., and Fofana, B. S. (2020). Seed yield and quality of three foundation seed models under the formal seed system, African Journal of Rural Development, Vol. 5 (2): pp.141-155.

11. De Groote, H., Dema, G., Sonda, G. B., \& Gitonga, Z. M. (2013). Maize for food and feed in East Africa-the farmers' perspective. Field Crops Research, 153, 22-36.

12. Doss, C. R. (2006). Analysing technology adoption using micro studies: limitations, challenges and opportunities for improvement. Agricultural Economics, 34(3): 207-219.

13. Edgerton, M. D. (2009). Increasing crop productivity to meet global needs for feed, food, and fuel. Plant physiology, 149(1), 7-13.

14. Food and Agriculture Organization of the United Nations/ World Food Programme, 2009. Integrating the Crop and Food Supply and the Emergency Food Security Assessments, Phase 2, FAO/WFP Crop and Food Security Assessment Mission to Ethiopia, Food and Agriculture Organization and World Food Programme: Rome, pp.20.

15. Hintze, H., Renkow, M. and Sain, G., 2002. Variety Characteristics, Transactions Costs and Maize Adoption in Honduras. Selected Paper in American Agricultural Economics Association meetings, Long Beach: CA, pp.3-6.

16. https://www.fao.org/3/y2722e/y2722e0d.htm

17. Kaliba, A. R., Verkuijl, M. H. and Mwangi, W., 2000. Factors Affecting Adoption of Improved Maize seeds and Use of Inorganic Fertilizer for Maize Production in the Intermediate and Lowland Zones of Tanzania. Journal of Applied Economics Association, 32(1): 35-47.

18. Kalinda, T., Tembo, G. and Asian, K. E. (2014). Adoption of improved maize seed varieties in Southern Zambia. Journal of Agricultural Sciences, 6(1): 33-39.

19. Kassie, M., Jaleta, M., Shiferaw, B., Mmbando, F. and De Groote, H. (2012). Improved Maize Technologies and Welfare Outcomes in Smallholder Systems: Evidence from Application of Parametric and Non-Parametric Approaches. In: Selected Paper IAAE Triennial Conference, IAAE: Foz do Iguaçu, Brazil: pp. 18-24.

20. Khan, M. I. K., Amin, A.K.M.R, Chowdhury, I. F., Mehraj, H., and Islam, S. (2015). Influence Of Seed Source On Growth And Yield Of Wheat, Scientific Journal of Seoul Sciences / 3 (3): 14-18

21. Lyon, F., \& Afikorah-Danquah, S. (1998). Small-scale seed provision in Ghana: social relations, contracts and institutions for micro-enterprise development. London, Network Paper No.84, UK.

22. Mavunganidze, M., Mwale, M., Mutenje, T., Chikuvire, J. and Tigere, T.A., (2013). Survival of Pseudomonas syringae pv. tomato in different soil types and moisture regimes. línea. Consultado, African Journal of Agricultural Research, 8(17): 1641-1649

23. McGuire, S. and L. Sperling (2011) 'The Links between Food Security and Seed Security: Facts and Fiction that Guide Response', Development in Practice 21(4-5): 493-508.

24. McGuire, S. J. (2008). Securing Access to Seed: Social Relations and Sorghum Seed Exchange in Eastern Ethiopia', Human Ecology 36(2): 217-229. 42

25. MoFA (2000). Food and Agriculture Sector Development Policy (FASDEP II). Retrieved from http://mofa.gov.gh/site/?page_id=598

26. MoFA (2012). Agriculture in Ghana: Facts and Figures. Accra: Ministry of Food and Agriculture, Statistics, Research, and Information Directorate.

27. Morris, M. L., Tripp, R. B., \& Dankyi, A. A. (1999). Adoption and impacts of improved maize production technology: A case study of the Ghana Grains Development Project.

28. Mutai, O. K. (2018). Effect Of Seed Source And Post-Harvest Handling Techniques On Seed Quality And Yield Of Soybean, Department Of Plant Science And Crop Protection, Faculty Of Agriculture, University Of Nairobi

29. Nchembi, N. S. (2017). Factors Influencing the Use of Improved Maize Seed Technology in Kilosa District in Tanzania, Lilongwe University of Agriculture and Natural Resources, Tanzania 
30. Nyamai, D. M. K. (2010). Determinants of Choice of Improved Maize Seeds in Arid and Semi-Arid Areas of Kenya: The Case of Yathui Division of Machakos District. University of Nairobi, Kenya

31. Oteng, J. W. (1997). Rice production and development in Ghana. Bulletin de la Commission Internationale du Riz (FAO); Noticiario de la Comision Internacional del Arroz (FAO).

32. Ouma, J., F. Murithi, W. Mwangi, H. Verkuijl, M. Gethi, and H. De Groote. (2002). Adoption of Maize Seed and Fertilizer Technologies. In Embu District, Kenya. Mexico, D.F. CIMMYT (International Maize and Wheat Improvement Center).

33. Owino, C.O. 2010. "Fertilizer Options for Sustainable Maize Production in Trans Nzoia District in Kenya," African Journal of Agricultural Research 5(11): 1208-1212.

34. Oyewo, I. O. (2011). Technical efficiency of maize production in Oyo State. Journal of Economics and International Finance, 3(4), 211.

35. Pixley, K., Bänziger, M., Córdova, H., Crossa, J., Dixon, J., Kanampiu, F. \& Warburton, M. (2009). Past and future innovations in tropical maize improvement. CIMMYT, Mexico.

36. Rahaman, K. A. (2018). Farmers' Practices in Soybean (Glycine Max) Storage And Their Effects On Viability And Vigour Of Seeds, Faculty of Agriculture, University For Development Studies

37. Ransom, J.K., Paudyal, K. and Adhikari, K. (2003). Adoption of improved maize varieties in the hills of Nepal. Agricultural Economics, 29(3): 299-305.

38. Sibiya, J., Tongoona, P., Derera, J. and Makanda, I., (2013). Farmers' desired traits and selection criteria for maize varieties and their implications for maize breeding: A case study from KwaZulu-Natal Province, South Africa. Journal of Agriculture and Rural Development in the Tropics and Subtropics, 114(1): 39-49.

39. Tripp, R. B. (1998). Regulatory issues: Varietal registration and seed quality control. Maize Seed Industries in Developing Countries (No. 338.1731521 MOR. CIMMYT). 